\title{
Germ cells and the seminiferous epithelium cycle in the wild rodent Oxymycterus rufus (Rodentia: Cricetidae)
}

\author{
${ }^{1}$ Ana Carolina T. Morais, ${ }^{1}$ Maytê K. Balarini, ${ }^{1}$ Tatiana P. Menezes, ${ }^{2}$ Fausto S. \\ Ferraz, ${ }^{3}$ Marcos L. M. Gomes, ${ }^{4}$ Danielle B. Morais, ${ }^{2}$ Tarcízio A. R. Paula, \\ ${ }^{1}$ Sérgio L. P. Matta \\ ${ }^{I}$ (Departamento de Biologia Geral, Universidade Federal de Viçosa, Brasil) \\ ${ }^{2}$ (Departamento de Medicina Veterinária, Universidade Federal de Viçosa, Brasil) \\ ${ }_{3}^{3}$ (Departamento de Biologia Estrutural, Universidade Federal do Triângulo Mineiro, Brasil) \\ ${ }^{4}$ (Departamento de Morfologia, Universidade Federal do Rio Grande do Norte Brasil)
}

\begin{abstract}
Oxymycterus rufus is a wild rodent that inhabits one of the world hotspots known as the Atlantic Rain Forest in Brazil. Due to the lack of reproductive data regarding such species, the present study aimed to describe O. rufus spermatogenic process through morphometrical and stereological analyses. To do so, testicular fragments of five sexually mature males were routinely processed for light and transmission electron microscopy. The results showed that each seminiferous epithelium cycle corresponded to 6.58 days, while the entire spermatogenic process lasted 29.61 days. The coefficient of spermatogonial mitoses was 5.64 and 2.79 spermatids were produced from each primary spermatocyte in pachytene. The spermatogenesis yield was 11.98 cells. The Sertoli cell index was 4.29, while its overall support capacity was 8.21 cells. The testicular sperm reserve was $183.5 \times 10^{6}$ cells, while $962.00 \times 10^{6}$ spermatids were found per gram of testis. The daily sperm production per testis and per gram of testis was $28.56 \times 10^{6}$ and $73.13 \times 10^{6}$ sperm, respectively. Therefore, the short duration of the seminiferous epithelium cycle along with rapid production of sperm indicates that $O$. rufus shows high efficiency in spermatogenesis.
\end{abstract}

Keywords: Mammal reproduction, Neotropical rodent species, Sertoli cell, spermatogenesis, testicle.

\section{Introduction}

The Atlantic Rain Forest is home to a rich mammalian fauna, composed of approximately 250 species, with a high degree of endemism: 55 species, mainly primates and rodents, are unique to this biome [1]. The order Rodentia is the most successful taxon considering abundance, diversity and distribution, comprising $44 \%$ of an overall 2,000 species within class Mammalia. In Brazil, the Cricetidae is the more diverse rodent family, which features 117 species grouped into 36 genera, all representing a single subfamily - the Sigmodontinae which contains the genus Oxymycterus [2], our experimental model.

In Brazil, the genus Oxymycterus if formed by nine species, with body size ranging from small to large $(11.5$ to $18 \mathrm{~cm})$, although the tail length is always shorter than the body. Two characteristics are common to all species: well developed claws and long snout [3]. They are also known to be terrestrial and semi-fossorial species, inhabiting forest edges in the Atlantic Rain Forest and in the Amazon Forest, as well as open areas such as paths and altitude fields in the Cerrado and Caatinga Biomes [2,3]. Oxymycterus spp. have a specialized diet consisting mostly by insects (70\%), being $25 \%$ of them termites [2], although other invertebrates and plants are often found [4]. The occurrence of Oxymycterus rufus was recorded only in a few localities in Southeastern Minas Gerais [5], picturing the lack of complete studies regarding to the endemic fauna [6].

Spermatogenesis is a complex cyclic process that takes place into the seminiferous tubules of sexually mature animals in which a diploid cell, the spermatogonia, gives rise to haploid sperm after meiotic division and differentiation [7]. In order to make sure that the whole process occurs in the right timing and place, the germ cells must be closely arranged and connected to each other, in a conformation known as a testicular stage [8]. When a whole series of specific changes occurs in these cell associations, which are in logical progression of development, we identify the process called seminiferous epithelium cycle (SEC) [9].

The description of seminiferous epithelium kinetics, along with testicular morphometry and stereology provide reliable information about the reproductive tissue as a whole and are fundamental tools to understand the reproductive biology of a given species $[10,11]$. Besides, scientific studies regarding the reproductive physiology of wild rodents is still scarce, which motivated us to develop the studies with the Sigmodontinae subfamily, starting with Oxymycterus nasutus [12]. 


\subsection{Ethics statement}

\section{Material and Methods}

The capture campaign, the animal use and surgical procedures were approved in accordance to the policies and principles established by the agency ICMBio/SISBIO (Chico Mendes Institute for Biodiversity Conservation, permit number: 22289-1). Five sexually mature $O$. rufus were sampled in an Atlantic Rain Forest fragment, located in Viçosa, Minas Gerais, Brazil (S 20 $81^{\prime}$ and W 42 $85^{\prime}$ ). The animals were captured in Sherman and Tomahawk traps distributed over the study area. Campaign's samples were collected monthly for five days and four nights. The animals were taken to the Laboratory of Structural Biology (DBG/UFV) and housed in polypropylene cages. Food and water were offered ad libitum. The field studies did not involve endangered or protected species. In addition, all surgical procedures were previously approved by the local ethics committee [Ethics Commission for Animal Use (CEUA/UFV) - permit number 76/012].

\subsection{Biometry}

Body and testes weight were recorded in order to get the biometrical indexes. The tunica albuginea of one testicle was dissected and weighed. This value was subtracted from the total testicular weight in order to obtain the testicular parenchyma weight.

\subsection{Light and transmission microscopy}

Testicular fragments were fixed in Karnovsky's solution (paraformaldehyde 4\% : glutaraldehyde 4\%, 1:1 in phosphate buffer $0.2 \mathrm{M}, \mathrm{pH} 7.3$ ) for 24 hours, and routinely processed for glycol methacrylate embedding (Historesin, Leica). Semi-serial sections ( $3 \mu \mathrm{m}$ thick), observing a minimum interval of $40 \mu \mathrm{m}$ between cuts, which were stained with toluidine blue/sodium borate $1 \%$. Morphometry was performed in digital images captured with a digital camera (Olympus, Q3color) coupled to the light microscope ocular (Olympus BX-40), and analyzed with the Image Pro Plus software (Media Cybernetics).

For transmission electron microscopy, testicle's fragments were fixed in $2.5 \%$ glutaraldehyde solution for $12 \mathrm{~h}$, and stored in cacodylate buffer $\left(0.1 \mathrm{~mol} / \mathrm{L}, \mathrm{pH} 7.4,4^{\circ} \mathrm{C}\right)$. The samples were post fixed in osmium tetroxide $1 \% /$ potassium ferrocyanide $8 \%(1: 1)$, for $2 \mathrm{~h}$. Thus, the material was dehydrated in ethanol and processed routinely to Spurr resin embedding (EMS). Ultrathin cuts were made and counterstained with uranil acetate $3 \%$ and lead citrate $3 \%$.

\subsection{SEC Stages}

SEC stages were characterized according to the tubular morphology method [13]. This method is based on the location of the spermatid's nucleus, the occurrence of meiotic division figures and the overall composition of the seminiferous epithelium, characterizing eight stages. Their relative frequency was determined after analyzing 200 random tubular cross-sections per animal.

\subsection{BrdU and SEC duration}

Three out of five animals were used for the BrdU experiment. Each of them received an intratesticular injection of $0.4 \mathrm{~mL}$ of 5-bromodeoxyuridine (BrdU - Invitrogen). The animals were euthanized 24, 48 and $72 \mathrm{~h}$ afterwards, by an overdose of xylazine hydrochloride $(150 \mathrm{mg} / \mathrm{kg})$ associated with ketamine hydrochloride $(10 \mathrm{mg} / \mathrm{kg})$.

In order to determine the SEC duration, testicular fragments of BrdU treated animals were embedded in paraplast (Sigma Aldrich) and $5 \mu \mathrm{m}$ sections were used. In brief, sections were rehydrated and washed in $0.1 \mathrm{~mol} / \mathrm{L}$ phosphate buffer (PBS), followed by blocking of endogenous peroxidase activity with hydrogen peroxide and methanol, for $10 \mathrm{~min}$. After further washing in PBS, sections were incubated with trypsin for 10 $\mathrm{min}$ in a humid chamber, at $37^{\circ} \mathrm{C}$. They were then washed in distilled water, performing denaturation for $45 \mathrm{~min}$ at room temperature. After further washing in PBS, the sections were incubated with a blocking solution for 10 $\mathrm{min}$, at room temperature. The anti-BrdU mouse monoclonal antibody was added for $2 \mathrm{~h}$. PBS was used for rinsing previously to the incubation with streptavidin-peroxidase for $10 \mathrm{~min}$. A mixture of hydrogen peroxide 5\% and DAB (3,3-diaminobenzidine) was used for developing in the dark. The sections were counterstained with hematoxylin and analyzed to detect the most advanced $\mathrm{BrdU}^{+}$cell type within the seminiferous epithelium after BrdU incorporation. Therefore, the frequency of stages traversed this period corresponds to the time interval of the incorporation until collection of the testicles, thus providing the period of one SEC, thus the complete spermatogenesis.

\subsection{Testicular Morphometry And Stereology}

The gonadosomatic index (GSI) was calculated by the formula: (testicles weight/body weight) x 100 [14]. The volume ratio occupied by the components of testicular parenchyma (seminiferous tubules and interstitium) was determined by counting 1000 points projected over 10 random images, thus quantifying the 
percentage of points over the seminiferous tubules (tunica propria, seminiferous epithelium and lumen) and interstitium. The parenchyma weight was calculated as the total testicular weight minus the tunica albuginea weight.

The volume of the parenchyma components $(\mathrm{mL})$ was calculated based on the testicular volume, which was considered equal to its weight [15]. The volume of the seminiferous tubules was determined from its percentage within the parenchyma: (\% of tubules/100) $x$ total volume of testicular parenchyma). Also, the volume of the seminiferous epithelium was obtained by dividing the percentage of the epithelium by 100 and multiplying by the weight of testicular parenchyma. The tubulesomatic index (TSI), which determines the investment in seminiferous tubules in relation to body mass, was determined after dividing the seminiferous tubules volume by the body weight, and the resulting value multiplied by 100 .

The tubular diameter was obtained from 30 tubular cross-sections per animal, as round as possible, regardless the SEC stage. The seminiferous epithelium height was measured using the same sections used to obtain the diameter. It was determined by the distance between the tunica propria and the luminal border. Two diametrically opposed measurements were made and the average used as a final result. Since the epithelium is the functional part of the tubule, the epithelium somatic (ESI) index was taken dividing the epithelium volume by the body weight and multiplying the result by 100 .

The total length (TL) of seminiferous tubules per testis, was estimated from the formula: $T L=S T V / \pi R^{2}$ (STV: seminiferous tubules volume; $\pi \mathrm{R}^{2}$ : area of the tubular cross-section; $\mathrm{R}=$ tubule diameter/2). The total length per gram of testis was calculated dividing TL by the testes weight.

\subsection{Germ cells counting}

The populations of Sertoli and germ cells were estimated by counting 10 seminiferous tubules crosssections in stage 1 of the SEC, per animal. Type A spermatogonia (A), primary spermatocytes at preleptotene/leptotene (PL/L), primary spermatocytes at pachytene (P), round spermatids (RS) and Sertoli cells (S) were quantified. Besides, the average nuclear diameter of each germ cell type and the nucleolar diameter of the Sertoli cells were measured. Thirty nuclei/nucleoli were used for each cell type. The results were corrected numerically due to variations in the size of the cells and the section thickness [16], being the results used to calculate the intrinsic efficiency of spermatogenesis.

The following indexes were calculated from the germ cell counting: the coefficient of spermatogonial mitosis efficiency (PL/A), the meiotic index (RS/P), which quantifies the efficiency of meiotic divisions, the overall spermatogenesis yield (RS/A), thus demonstrating the efficiency of this process as a whole.

\subsection{Sertoli cells}

The total number of Sertoli cells was determined from the value of the seminiferous tubules length multiplied by the corrected number of Sertoli nucleoli, and the result divided by the cut thickness. The number of Sertoli cells per gram of testis was obtained by dividing the total cell number by the testicular weight. The total Sertoli cell support capacity was calculated using the sum of all germ cells types divided by the number of Sertoli cells $((A+P L / L+P+R S) / S)$. Also, the Sertoli cell index was calculated by dividing the number of round spermatids by the Sertoli cells number.

The testicular sperm reserves (TSR; total and per gram of testis) was determined using the round spermatids population in stage 1 of the SEC (the spermiogenesis loss was considered insignificant). For so, the average number of round spermatids per tubule cross-section was obtained, being corrected for the total length of the tubule per testis or per gram of testis, using the formula: $T S R=[(T L /$ section thickness $) x R S)][13]$. In order to calculate the daily sperm production (DSP) the TSR was divided by the duration of one SEC. Also, to determine the DSP per gram of testis, the DSP was divided by the testes weight.

\subsection{Statistics}

Data were analyzed using the statistical function of the Excel (Windows 7) and are showed as mean and standard deviation. $P<0.05$ was considered significant.

\subsection{Morphometry and stereology}

\section{Results}

The volumetric proportions for the tubular compartment are shown in Fig. 1. Body weight was $82.28 \mathrm{~g}$ and the weight of both testes was $0.384 \mathrm{~g}$. The resulting GSI was $0.47 \%$. The tunica albuginea weight $(0.026 \mathrm{~g})$ was used to obtain the value of the testicular parenchyma $(0.358 \mathrm{~g})$.

The tubular component of $O$. rufus corresponds to $90.91 \%$ of the testicular parenchyma, while the remaining percentage $(9.09 \%)$ is equivalent to the interstitium. The volume of the seminiferous epithelium was $0.290 \mathrm{~mL}$, while the ESI and TSI were 0.35 and $0.40 \%$, respectively. The seminiferous tubule diameter was 
Germ cells and the seminiferous epithelium cycle in the wild rodent Oxymycterus rufus (Rodentia:..

$175.45 \mu \mathrm{m}$ and the height of the seminiferous epithelium was $61.04 \mu \mathrm{m}$. The total lengths of the seminiferous tubules per testicle and per gram of testicle were $13.40 \mathrm{~m}$ and $34.93 \mathrm{~m}$, respectively (Table 1 ).

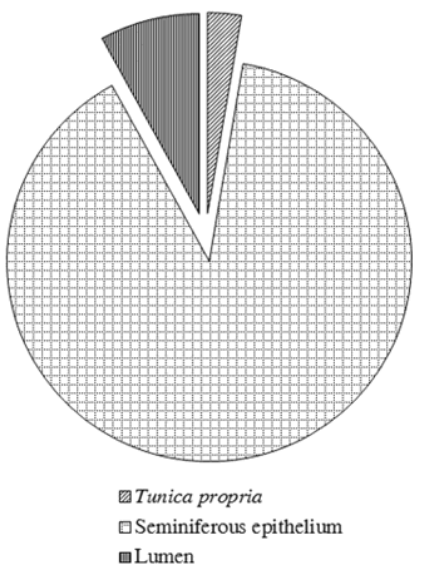

Fig. 1. Stereology of the testicular parenchyma of Oxymycterus rufus.

\begin{tabular}{|lc|}
\hline Volumetric proportion $(\%)$ & Mean \pm SEM \\
\hline Tubular compartment & $90.91 \pm 4.09$ \\
\hline Tunica propria & $2.44 \pm 1.01$ \\
\hline Lumen & $7.27 \pm 4.09$ \\
\hline Seminiferous epithelium & $81.20 \pm 6.54$ \\
\hline
\end{tabular}

Table 1.Seminiferous tubules morphometry and stereology

\begin{tabular}{|l|c|}
\hline Parameters & Mean \pm SD $(\mathbf{n}=\mathbf{5})$ \\
\hline Tubular diameter $(\mu \mathrm{m})$ & $175.45 \pm 18.48$ \\
\hline Seminiferous epithelium height $(\mu \mathrm{m})$ & $61.04 \pm 5.90$ \\
\hline Tubular volume $(\mathrm{mL})$ & $0.32 \pm 0.10$ \\
\hline Seminiferous epithelium volume $(\mathrm{mL})$ & $0.29 \pm 0.10$ \\
\hline Epitheliumsomatic index $(\%)$ & $0.35 \pm 0.14$ \\
\hline Tubulesomatic index $(\%)$ & $0.40 \pm 0.15$ \\
\hline Total tubular length per testis $(\mathrm{m})$ & $13.40 \pm 2.51$ \\
\hline Tubular length per gram of testis $(\mathrm{m})$ & $34.93 \pm 5.37$ \\
\hline
\end{tabular}

\subsection{SEC stages and relative frequency}

Stage 1-The epithelium composition showed 3-4 layers of round spermatids around the luminal border. Pachytene spermatocytes were found right below them, being very characteristic cells, with their large nucleus with obvious chromatin pattern. Pre leptotene/leptotene spermatocytes were located next to the tunica propria, as well as the type A spermatogonia, observed in all stages. Sertoli cell's round or triangular nuclei were located near to the tunic, with clear nucleoli, often aligned with two other smaller ones (Fig. 2A).

Stage 2-Spermiogenesis began with spermatid's slowly elongation and chromatin condensation. Spermatids were oriented toward the Sertoli cell nuclei in the base of the epithelium. Pachytene spermatocytes were located among the elongating spermatids and preleptotene/leptotene spermatocytes, composing an intermediate layer within the germinal epithelium (Fig. 2B).

Stage 3-During the elongation process, the spermatids were grouped in defined bundles and inserted between layers of diplotene primary spermatocytes, which were the largest cells within the epithelium. Below these were primary zygotene spermatocytes. Type-A spermatogonia and Sertoli cell nuclei were still clearly seen on the basis of the epithelium (Fig. 2C).

Stage 4-The primary spermatocytes at stage 4 exhibited the metaphase plate, representing the progression of diplotene from the prior stage. Different cell types were present, as follows: two types of primary spermatocytes, some in transition from zygotene into pachytene, while others reaching the diplotene phase; secondary spermatocytes and elongated spermatids (Fig. 2D).

Stage 5-Two distinct generations of spermatids were observed: those undergoing elongation since stage 2, and the newly formed at the end of meiosis I. The elongated ones were arranged in well-defined bundles and deeply inserted in the epithelium. Zygotene and pachytene spermatocytes were also observed. Sertoli cell's nuclei were perpendicular to the basal lamina and close to the type A spermatogonia (Fig. 2E).

Stage 6-Groups of elongated spermatids began to unravel, losing the bundle pattern and beginning its shift toward the tubular lumen. They were composed of less cytoplasm and smaller nuclei, with highly condensed chromatin. The newly formed round spermatids were arranged into 3 or 4 layers close to the tubular lumen. Below them, and closer to the basal environment, the pachytene spermatocytes were found. Sertoli cells maintained the characteristics seen on the previous stage, while type-A spermatogonia originated intermediate spermatogonia, with smaller and darker nuclei (Fig. 2F).

Stage 7-The elongated spermatids within the bundles were more separated from each other and closer to the tubular lumen, showing more ovoid nuclei, when compared to those seen at stage 6 . Besides the cells found in 
Germ cells and the seminiferous epithelium cycle in the wild rodent Oxymycterus rufus (Rodentia:..

the previous stage, type-B spermatogonia originated from intermediate spermatogonia are present. Mitotic divisions are commonly observed in the basal environment, which are due to the constant divisions of type-B spermatogonia giving rise to preleptotene spermatocytes (Fig. 2G).

Stage 8-Type-A spermatogonia and Sertoli cells were observed at the base of the germinal epithelium, as well as preleptotene spermatocytes originated from type-B spermatogonia. Pachytene spermatocytes were present in the inner portion of the adluminal environment, whereas layers of round spermatids originated in stage 5 were close to the tubular lumen. The elongated spermatids were located in the luminal border with their tails facing the lumen of the tubule, ready for spermiation. Remains of the cell membrane and cytoplasm resulting from the spermiogenesis were also evident on the edge of the lumen as residual bodies (Fig. 2H).
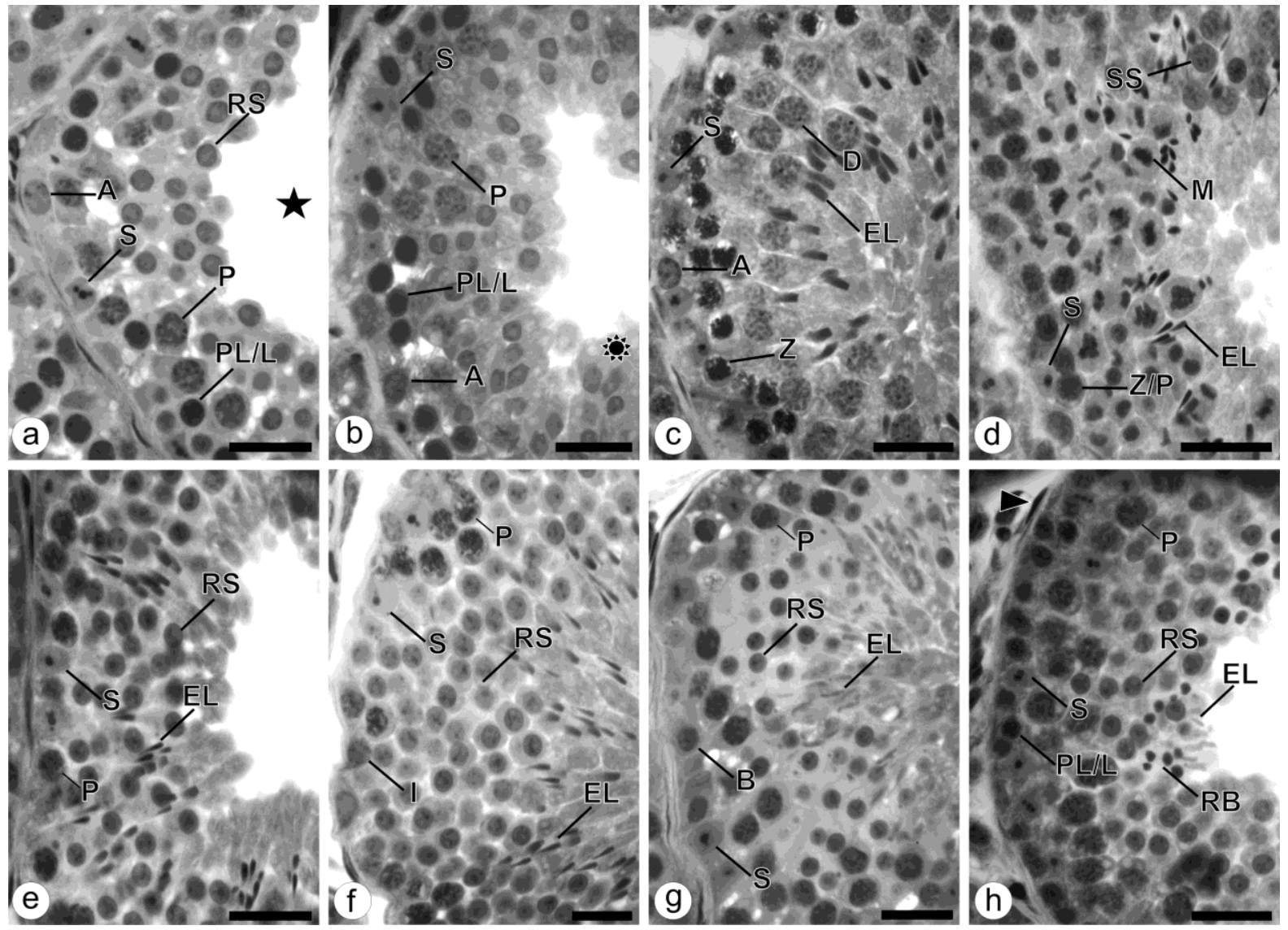

Fig. 2. Stages 1-8 of the SEC in $O$. rufus. Sertoli cell (S); type-A spermatogonia (A); intermediate spermatogonia (I); type-B spermatogonia (B); preleptotene/leptotene spermatocyte transition (PL/L); zygotene spermatocyte (Z); zygotene/pachytene spermatocyte transition $(\mathrm{Z} / \mathrm{P})$; pachytene spermatocyte $(\mathrm{P})$; diplotene spermatocyte (D); secondary spermatocyte (SS); meiotic figure (M); round spermatids (RS); elongate spermatids (EL); elongating spermatids (nine point star); residual bodies (RB); lumen of the seminiferous tubule (star); tunica propria (arrow head). Bars: $20 \mu \mathrm{m}$.

\subsection{Stage frequency}

The relative frequencies of the 8 SEC stages are illustrated in Fig. 2. Stage 1 showed the highest frequency (18\%) and its duration was estimated at 5.33 days, while stage 4 was less frequent $(6.4 \%)$, corresponding to 1.9 days. The pre-meiotic phase represented $45.6 \%$, while the meiotic and the post-meiotic represented $6.4 \%$ and $48 \%$, respectively, lasting 13.5, 1.9 and 14.2 days in terms of duration within the whole cycle, respectively (Fig. 3).

\subsection{Spermatids Ultrastructure}

Different spermatids were identified based on the acrosome development (Fig. 4). The newly formed round spermatids in stage 5 did not show an acrosome vesicle (Fig. 4A), while those in stage 1 (Fig. 4B) present acrosome formation. The elongation phase, which begins in stage II, shows the gradual development of the acrosome (Fig. 4C). Cells with elongated nucleus in stage 3 (Fig. 4D) and with very electron-dense nucleus, found in stage 7, were also identified (Fig. 4E). 
Germ cells and the seminiferous epithelium cycle in the wild rodent Oxymycterus rufus (Rodentia:..

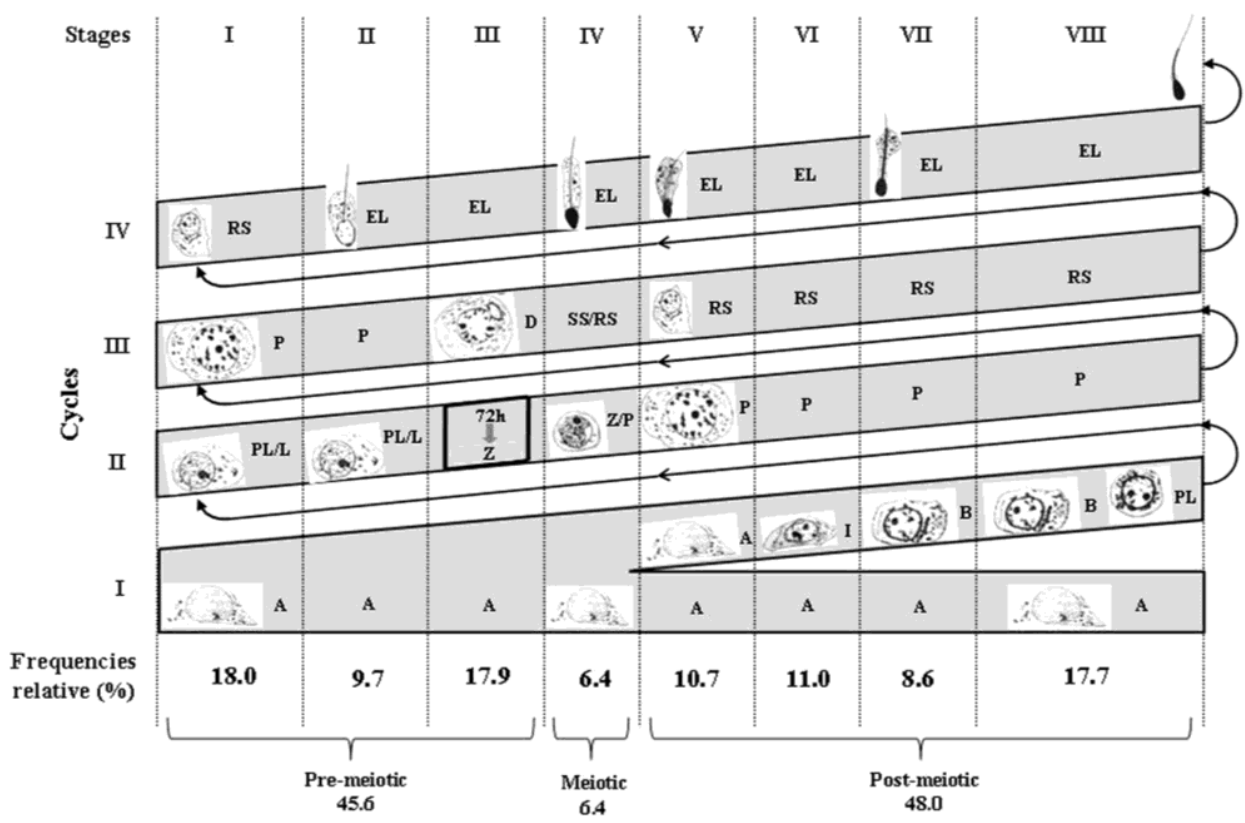

Fig. 3. Relative frequency of the SEC in $O$. rufus. Each line corresponds to a cell generation, whereas each column represents one of the eight stages of the SEC. Type-A spermatogonia (A); intermediate spermatogonia (I); type-B spermatogonia (B); preleptotene/leptotene spermatocyte (PL/L); zygotene spermatocyte (Z); zygotene/pachytene spermatocyte (Z/P); pachytene spermatocyte $(\mathrm{P})$; diplotene spermatocyte $(\mathrm{D})$; secondary spermatocyte (SS); round spermatids (RS); elongated spermatids (EL).

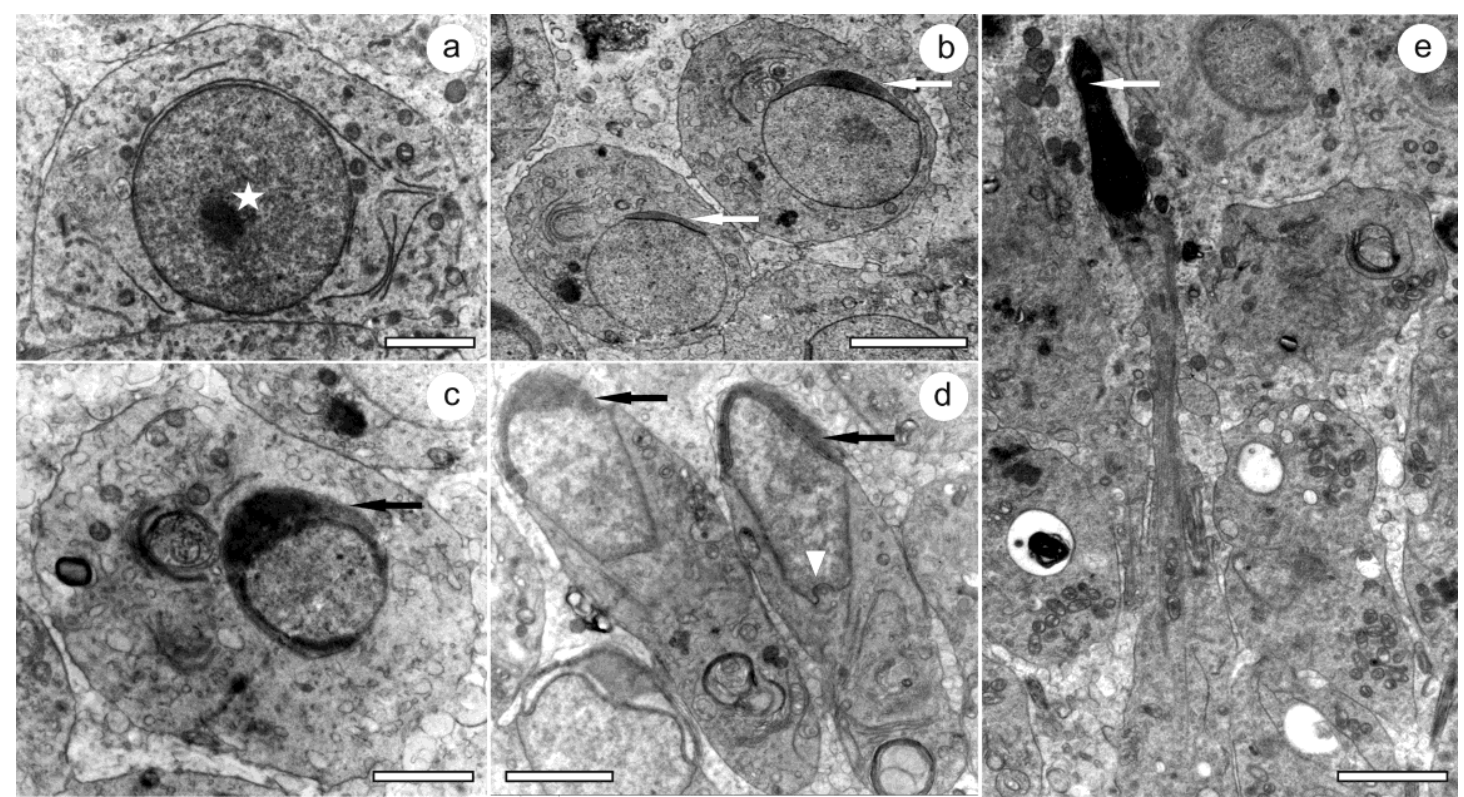

Fig. 4. Nuclear ultrastructure of spermatids at different stages of acrosome development in $O$. rufus. (A) Round spermatid without acrosome - stage 5; (B) round spermatids with developing acrosomal cap - stage 1; (C-D) spermatids elongation phase with developing acrosomal cap - stages 2 and 3, respectively; (E) elongated spermatid with completed acrosome - stage 7; nucleolus (star); acrosomal cap (arrow); flagellum formation (arrow head). Bars: (A; C; D; E) $2 \mu \mathrm{m}$; (B) $5 \mu \mathrm{m}$.

\subsection{SEC duration}

BrdU labeling appeared in primary spermatocytes in zygotene after $72 \mathrm{~h}$ of incubation. These cells were the most advanced in spermatogenesis, being detected in stage 3 (Fig. 5). The seminiferous epithelium cycle progressed $45.6 \%$ after three days (average frequency of the stage 1 to 3 ), thus taking 6.58 days for a complete cycle. Knowing that 4.5 cycles are required for the completion of spermatogenesis, the whole cycle takes 29.61days to happen in $O$. rufus. 


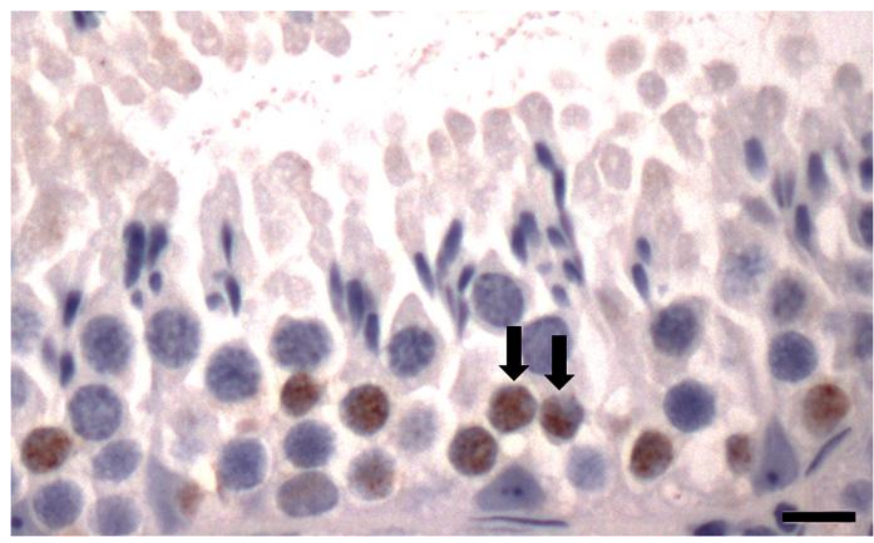

Fig. 5.BrdU staining. Zygotene spermatocytes are positive to BrdU in stage 3 (arrows), 72 hours after injection in the testis of O. rufus. Bar: $10 \mu \mathrm{m}$.

\subsection{Germ cell counting}

Each seminiferous tubule cross-section in stage 1 showed 3.43 type-A spermatogonia, 19.36 preleptotene/leptotene spermatocytes, 14.70 pachytene spermatocytes, 41.09 round spermatids and 9.57 Sertoli cells (Table 2). The average nuclear diameter was registered for each germ cell type as follows: $8.52 \mu \mathrm{m}$ for type-A spermatogonia, $6.87 \mu \mathrm{m}$ for preleptotene/leptotene spermatocytes, $9.28 \mu \mathrm{m}$ for pachytene spermatocytes, and $5.76 \mu \mathrm{m}$ for round spermatids. Sertoli cells exhibited nucleolar average diameter of $1.89 \mu \mathrm{m}$.

The indexes for the intrinsic efficiency of spermatogenesis are shown in Table 2. The coefficient of the efficiency of spermatogonial mitosis has shown that on average, each type-A spermatogonia at the beginning of spermatogenesis yielded 5.64 preleptotene/leptotene spermatocytes. An important cell loss was observed in meiotic prophase, since the population of spermatocytes at pachytene (14.70) was reduced when compared to the population of preleptotene/leptotene spermatocytes (19.36). The meiotic yield was 2.79 round spermatids per spermatocyte at pachytene, representing $69.75 \%$ of efficiency, while the spermatogenesis yield corresponded to 11.97 round spermatids produced from a single type-A spermatogonia.

Table 2. Cell populations and spermatogenesis yield in $O$. rufus.

\begin{tabular}{|l|c|}
\hline Parameters & Mean \pm SD $(\mathrm{n}=5)$ \\
\hline Type A spermatogonia & $3.43 \pm 0.68$ \\
\hline Preleptotene spermatocyte & $19.36 \pm 5.27$ \\
\hline Pachytene spermatocyte & $14.70 \pm 3.00$ \\
\hline Round spermatids & $41.09 \pm 9.96$ \\
\hline Sertoli cell & $9.57 \pm 0.98$ \\
\hline Coefficient efficiency of spermatogonial mitosis & $5.64 \pm 2.57$ \\
\hline Meiotic yield & $2.79 \pm 0.71$ \\
\hline Spermatogenic yield & $11.98 \pm 3.15$ \\
\hline
\end{tabular}

The Sertoli cell's indexes along with the spermatic production data can be found in Table 3. The Sertoli cell showed the capacity to support an average of 4.29 round spermatids, while 8.21 cells were supported by the same cell when the whole germ cell lineage was considered. Regarding the number of Sertoli cells, each testicle contained $42.21 \times 10^{6}$ Sertoli cells or $232.4 \times 10^{6}$ cells per gram of the organ.

The efficiency of spermatogenesis was calculated based on the testicular sperm reserves (TSR) and the daily sperm production (DSP) (Table 3). The observed sperm reserves per testis and per gram of testis were $183.5 \times 10^{6}$ and $962.0 \times 10^{6}$ spermatids, respectively. Once it known that the calculated SEC was 6.58 days, it was possible to calculate the DSP, which reached $28.56 \times 10^{6}$ spermatozoa per testis or $73.13 \times 10^{6}$ per gram of testis.

Table 3.Cells counting and testicular indexes of $O$. rufus

\begin{tabular}{|l|c|}
\hline Parameters & Mean \pm SD $(\mathbf{n}=\mathbf{5})$ \\
\hline Sertoli cell index (round spermatids / Sertoli) & $4.29 \pm 1.50$ \\
\hline Total capacity support Sertoli cell & $8.21 \pm 1.77$ \\
\hline Sertoli cell per gram of testis $\left(\mathrm{x} 10^{6}\right)$ & $232.40 \pm 5.55$ \\
\hline Sertoli cell per testis $\left(\mathrm{x} 10^{6}\right)$ & $42.21 \pm 5.02$ \\
\hline Spermatic reserve per gram of testis $\left(\mathrm{x} 10^{6}\right)$ & $962.00 \pm 1.11$ \\
\hline Spermatic reserve per testis $\left(\mathrm{x} 10^{6}\right)$ & $183.50 \pm 7.41$ \\
\hline Daily spermatic production per gram of testis $\left(\mathrm{x} 10^{6}\right)$ & $73.13 \pm 8.40$ \\
\hline Daily spermatic production per testis $\left(\mathrm{x} 10^{6}\right)$ & 28.56 \\
\hline
\end{tabular}




\section{Discussion}

This is the first study that provides comprehensive data on the spermatogenesis of the wild rodent $O$. rufus. The order Rodentia was characterized as the one that shows the greatest variation of the ratio testis/body weight among 62 rodents (from $0.05 \%$ in Castor canadensis to $8.41 \%$ in Tatera indica) [10]. In addition, it has been observed that the largest allocation and high energy expenditure in testicular mass were found in small animals, as well as in $O$. rufus. Despite higher than the observed in larger rodents of the suborder Hystricomorpha [17,18], the GSI found for O. rufus was lower than the obtained for other subjects from the suborder Myomorpha [19]. Different GSI values between suborders takes place due to the system of reproduction, since the testicles size is also related to the reproductive behavior, when monogamous or polygynous species show lower GSI than promiscuous species [10]. The pattern here described for $O$. rufus corroborates the description of the mating pattern for most rodents, in which promiscuity prevails [20].

The seminiferous tubules compartment exerts great influence on the parenchyma weight, being very important in a given species, since it is the site of sperm production, with [7,14]. Despite being a new tool in testicular stereology, it is expected that animals with high investment rates of sperm production show high tubulesomatic indexes [10]. Although the volumetric proportion of this component remained within the gap found for the most studied mammals (60 to 90\%) [7], the TSI found for O. rufus was higher than in other rodents, mainly due to its small body weight [21]. In order to have a better understanding of the dynamics of the spermatogenic cycle we must consider other parameters such as the diameter of the seminiferous tubules, the germ and somatic cells populations and the length of the seminiferous epithelium cycle (SEC).

The seminiferous tubules diameter and the seminiferous epithelium height are reliable measurements in the evaluation of sperm production, since they show the variations through the SEC [22]. The average diameter and epithelial height observed in $O$. rufus were within the range described for most amniotes species [7,23], and similar to Hystricomorpha, however lower than in other Myomorpha species [24,25]. On the other hand, we believe that the epitheliumsomatic index (ESI) would be a better parameter to compare animals from different suborders, since it quantifies the amount of seminiferous epithelium regarding to body weight and is directly associated with sperm production [22]. O. rufus showed an elevated ESI, reinforcing the previously described hypothesis that assume that the smaller the animals the higher the ESI and energy expenditure in testicular mass, leading to a higher sperm production [10]. In addition, the length of the seminiferous tubules per gram of testis found for $O$. rufus was similar to other Cricetidae [19].

The seminiferous epithelium cycle is divided into 3 distinct phases: a, the pre-meiotic phase that takes place between spermiation and metaphase I (stages 1-3), b, the meiotic phase when the two meiotic divisions take place (stage 4), and c, the post-meiotic phase that comprises all stages after the completion of the meiotic divisions until spermiation (stages 5-8) [7,26]. In the present study, pre- and post-meiotic phases showed similar frequencies within the cycle. The meiotic phase was longer than what is currently observed the observed in domestic mammals - 10\% [7] but similar to A. cursor and O. nigripes [27]. The eight stages of the SEC were distributed in a segmental arrangement along the seminiferous tubule, a pattern described for most mammals, except primates [28]. The average frequency of each stage of the SEC is considered a constant variable in individuals of the same species [7]. The most frequent stage in O. rufus was stage 1, as well as previous observations in wild rodents [18].

The duration of the SEC is a species-specific parameter, which is controlled by the genotype of the germ cells as well as the relative frequency of each stage [7,29]. The average duration of a spermatogenic cycle in rodents is slightly faster ( 8 to 12 days) than in other mammalian species ( 9 to 14 days) [9,30]. The duration of the SEC in $O$. rufus was remarkably low, even when compared to the lowest values registered so far, for the rodents D. leporina [21] and Cleterionomys glareolus [31]. Also, the data shown for O. rufus was lower than other Myomorpha and Hystricomorpha [17,18,24], which would be explained by the mating strategy. Promiscuous animals, such as $O$. rufus, show shorter cycles with fast sperm production, reflecting an adaptation to competition between males for fertilization [32].

The testicular sperm reserve (TSR) estimates the number of sperm produced on each SEC [13]. The TSR in O. rufus was higher than the described for domestic mammals [7] and Hystricomorpha [33], due to the longer seminiferous tubules. Moreover, the higher TSR value is commonly associated with the promiscuous behavior, whereas monogamous mating systems show lower TSR [17].

One way to determine the efficiency of the spermatogenic process is establishing numerical ratios between type-A spermatogonia and other germ cell types, allowing comparisons between subjects, and the quantification of cell loss that usually occurs during cell division [34,35]. The efficiency of spermatogonial mitosis represents the number of preleptotene/leptotene spermatocytes originated from each type-A spermatogonia [36]. Six generations of spermatogonia are usually described for most mammals, resulting in up to 64 cells by the end of the mitotic phase [9]. In $O$. rufus this efficiency was remarkably low $(8.82 \%)$, in which approximately $90 \%$ of all cells was lost. Germ cell apoptosis during specific stages of the SEC may represent the removal of cells that have incomplete genetic components or even chromosomal abnormalities [37,38]. 
Germ cells and the seminiferous epithelium cycle in the wild rodent Oxymycterus rufus (Rodentia:..

Furthermore, apoptosis plays an important role in regulatory mechanisms to maintain the appropriate number of germ cells for each Sertoli cell, as well as the architecture and position of germ cells within the epithelium [39]. Despite being an expressive value it still remains close to the amplitude of cell loss described for domestic and wild mammals (60-90\%) [7,40]. Moreover, the lower cell loss occurs during the meiotic phase (5 to 30\%) [7], and considering the overall efficiency of this phase, four round spermatids are expected from each primary spermatocyte. In $O$. rufus the meiotic yield reached $69.75 \%$, within the range reported for other rodents [18,24].

The spermatogenic yield is obtained by dividing the number of spermatogonia and spermatids, since cell loss during spermiogenesis is considered not significant [7]. The high number of type-A spermatogonia found in $O$. rufus lead to a low spermatogenesis yield, considering the results found for Myopomorpha [27].

The calculation of the DSP is obtained from the duration of a SEC and the knowledge of TSR, the latter being a species-specific parameter. Furthermore, the daily sperm production per gram of testis is a way to measure the spermatogenesis efficiency and can be used in interspecific comparisons [41,42]. In $O$. rufus, the DSP per gram of testis was similar to other Myomorpha [19] although higher than in Hystricomorpha [21].

Sertoli cells play a crucial role in the regulation of spermatogenesis, with a topographical and functional coordination [7,43]. Their population is stable in adults, even in different stages of the SEC, which makes them an important reference point to quantify and functionally evaluate spermatogenesis [34]. The number of Sertoli cells per gram of testis was far above the values observed for other Myomorpha [19], thus compensating their lower support capacity (8.21 cells) when compared to other mammalian species (11 to 37 cells) $[7,36,44,45]$. The high spermatogenic efficiency correlates the proportion and length of the seminiferous tubules, the number of Sertoli cells per gram of testis and their support capacity with a short duration of spermatogenesis $[16,30,35]$.

The ultrastructural evaluation of different types of spermatids allows us to follow the origin and development acrosome. The acrosome biogenesis takes place after initiating by a vesicular transport pathway from the endoplasmic reticulum to the Golgi complex apparatus, where two types of vesicles are produced: one proacrosomal and one non-acrosomal. Both vesicles follow to opposite poles of the cell surface. The first type will form the acrosome itself, while the second type will contribute to the formation of the spermatid's flagellum from the centrosome [46]. The pro-acrosomal vesicles carry pro-acrosomal granules within, which are transported by motor proteins such as actin over the microtubules. The vesicles coalesce into a single granule, called the acrosomal vesicle, which flattens at the moment that makes contact with the nuclear surface, thereby forming the acrosomal cap (Russell et al. 1990). Then, the cap attached to the nuclear surface begins its descent along the nucleus [47]. The nucleus progressively elongates, the Golgi complex departs from the acrosome and migrates to the caudal pole of the cell. At this point, the acrosome appears to cease its growth, although suffers gradual density increasing [9].

\section{Conclusion}

The parameters evaluated in the present study defined Oxymycterus rufus as a promiscuous species due to the short duration of the seminiferous epithelium cycle, which enables the rapid production of sperm within the seminiferous tubules. The high relative number of Sertoli cells was responsible to keep a high spermatogenesis efficiency compared to other subject of the suborder Myomorpha, even with reduced support capacity of this cell type

\section{Acknowledgments}

The authors wish to thank the NGO Ambiente Brasil, for the sampling logistics. Also, to the Núcleo de Microscopia e Microanálise (UFV), for the help with the transmission electron microscopy technique. The authors attest that there is no conflict of interest to declare.

\section{References}

[1]. L. Costa, Y.Lr. Leite, S.L.Mendes and A.D. Ditchfield, Conservação de mamíferos no Brasil, Megadiversidade, 1: 2005 , $103-112$.

[2]. J.A. Oliveira and C.R. Bonvicino, Ordem Rodentia, in N.R. Reis, A.L. Peracchi, W.A. Pedro and I.P. Lima, (Eds.), Mamíferos do Brasil (Londrina: Paraná. 2006), 347-400.

[3]. C.R. Bonvicino, J.A. Oliveira and O.S. D'Andrea, Guia dos roedores do Brasil, com chaves para gêneros baseadas em caracteres externos (Centro Pan-Americano de Febre Aftosa - OPAS/OMS, 2008).

[4]. F.O. Kravetz, Estudio del régimen alimentario, períodos de actividad y otros rasgos ecológicos en una población de "ratón hocicudo" (Oxymycterus rufus platensis, Thomas) de Punta Lara, Acta Zoologica Lilloana, 29: 1972, 201-212.

[5]. P.R. Gonçalves and J.A. Oliveira, Morphological and genetic variation between two sympatric forms of the genus Oxymycterus (Rodentia: Sigmodontinae): an evaluation of hypotheses of differentiation within the genus, Journal of Mammalogy, 85: 2004, 148161.

[6]. D.E. Wildt, Lions, Tigers, and Pandas, Oh My, Journal of Andrology, 26: 2005, 452-454.

[7]. L.R. França and L.D. Russell, The testis of domestic animals, in F. Martínez and J. Regadera (Eds.), Male reproduction. A multidisciplinary overview (Madrid: Churchill Livingstone, 1998), 197-219.

[8]. C.P. Leblond and Y. Clermont, Definition of the stages of the cycle of the seminiferous epithelium in the rat, Annals of the New York Academy of Sciences, 55: 1952, 548-584. 
Germ cells and the seminiferous epithelium cycle in the wild rodent Oxymycterus rufus (Rodentia:..

[9]. L.D. Russell, R.A. Ettlin, A.P. Sinha-Hikim and E.D. Clegg, Mammalian spermatogenesis, in L.D. Russell, R.A. Ettlin, A.P. SinhaHikim and E.D. Clegg. (Eds.), Histological and Histopathological Evaluation of the Testis (Clearwater: Cache River Press, Florida. 1990), 1-40.

[10]. G.J. Kenagy and S.C. Trombulak, Size and function of mammalian testis in relation to body size, Journal of Mammalogy, 67: 1986, $1-22$.

[11]. M.H.F. Azevedo, T.A.R. Paula, S.L.P. Matta, C.C. Fonseca, E.P. Costa, D.S. Costa and J.V. Peixoto, Cell population indexes of spermatogenic yield and testicular sperm reserves in adult jaguars (Panthera onca), Animal Reproduction Science, 118: 2010, 8388.

[12]. A.C.T. Morais, M.K. Balarini, E.O. Lopes,T.P.vMenezes, F.M.Quintela,D.B. Morais, M.L.M. Gomes, S.L.P. Matta, The tubular compartment and the spermatogenic dynamicsof the wild rodent Oxymycterus nasutus (Rodentia: Cricetidae), Animal Reproduction Science, 149: 2014, 249-258.

[13]. W.E. Berndtson, Methods for quantifying mammalian spermatogenesis: a review, Journal of Animal Science, 44: 1977, 818-883.

[14]. R.P. Amann, Sperm production rates, in A.D. Jhonson, W. R. Gomes and N. L. Vandermark (Eds.), The testis (New York: Academic Press, 1970), 433-482.

[15]. L. Johnson, C.S. Petty and W.B. Neaves, A new approach to qualification of spermatogenesis and its application to germinal cell attrition during human spermatogenesis, Biology of Reproduction, 25: 1980, 217-226.

[16]. R.P. Amann, Reproductive capacity of diary bulls. IV. Spermatogenesis and testicular germ cell degeneration, American Journal of Anatomy, 110: 1962, 69-78.

[17]. T.A.R. Paula, S.L.P. Matta and D.S. Costa, Avaliação histológica e quantitativa do testículo de capivaras (Hydrochoerus hydrochaeris), Bioscience Journal, 18: 2002, 121-136.

[18]. G.M. Costa, M.C. Leal, A.C. Ferreira, D.A. Guimarães and L. R. França, Duration of spermatogenesis and spermatogenic efficiency in two large Neotropical rodent species: the agouti (Dasyprocta leporina) and paca (Agouti paca), Journal of Andrology, 31: 2010, 489-499.

[19]. D.A. Cordeiro Júnior, Estrutura e função testiculares em roedores silvestres das famílias Echimyidae (Trinomys moojeni) e Cricetidae (Akodon cursor, Akodon montensis, Necromys lasiurus e Oligoryzomys nigripes), da Reserva Particular do Patrimônio Natural do Caraça - MG, doctoral diss., Universidade Federal de Minas Gerais, Belo Horizonte, MG, Brasil. 2009

[20]. J. Waterman, Male mating strategies in rodents, in J.O. Wolff and P.W. Sherman (Eds.), Rodent Societies: An Ecological and Evolutionary Perspective (London: The University of Chicago Press, 2007), 27-41.

[21]. M. Carretta Júnior, Estudo comparativo do processo espermatogênico e duração do ciclo do epitélio seminífero através da técnica de imunohistoquímica com bromodeoxiuridina de três diferentes espécies de roedores da subordem Hystricomorpha: cutia (Dasyprocta leporina), paca (Cuniculus paca) e capivara (Hydrochoerus hydrochaeris), doctoral diss., Universidade Federal de Viçosa, Viçosa, MG, Brasil, 2012.

[22]. T.Y. Wing and A.K. Christensen, Morphometric studies on rat seminiferous tubules, American Journal of Anatomy, 165: 1982, 1325.

[23]. E. C. Roosen-Runge, The process of spermatogenesis in animals. (Cambridge: Cambridge University Press, 1977).

[24]. D.A. Cordeiro Júnior, G.M.J. Costa, A.S. Talamoni and L.R. França. Spermatogenic efficiency in the spiny rat, Trinomys moojeni (Rodentia: Echimyidae), Animal Reproduction Science, 119: 2010, 97-105.

[25]. F.C.S.A. Melo, T.P. Sousa, K.L.C. Costa, S.L.P. Matta, F.R. Melo and R.M. Santa-Rita. Descriptive morphometry and stereology of the tubular compartment in the wild rodent Hylaeamys megacephalus (Rodentia: Cricetidae) from Central Brazil, Animal Reproduction Science, 138: 2013, 110-117.

[26]. M. Courot, M.T. Hochereau-de-Reviers and R. Ortavant, Spermatogenesis. in A.D. Johnson, W.R. Gomer and N.L. Vandemark, (Eds.), The Testis (New York: Academic Press, 1970), 399-432.

[27]. M.K. Balarini, Morphofunctional evaluation of the testis and spermatogenesis of wild rodents Akodon cursor (Winge, 1887) and Oligoryzomys nigripes (Olfers, 1818) (Rodentia: Cricetidae), doctoral diss., Universidade Federal de Viçosa, Viçosa, MG, Brasil, 2013.

[28]. L.R. França and F.M. Cardoso, Duration of spermatogenesis and sperm transit time through the epididymis in the piau boar, Tissue \& Cell, 30: 1998, 573-582.

[29]. L.R. França, T. Ogawa, M.R. Avarbock, R.L. Brinster and L.D. Russell, Germ cell genotype controls cell cycle during spermatogenesis in the rat, Biology of Reproduction, 59: 1998, 1371-1377.

[30]. R.A. Hess and L.R. França, Spermatogenesis and cycle of the seminiferous epithelium. in C.Y. Cheng (Ed.), Molecular mechanisms in spermatogenesis. (New York: Landes Bioscience, 2007), 1-15.

[31]. C.A. Grocock and J.R. Clark, Duration of spermatogenesis in the vole (Microtus agrestis) and the bank vole (Cleterionomys glareolus), Journal of Reproduction and Fertility, 47: 1976, 133-135.

[32]. E.J. Peirce and W.G. Breed, A comparative study of sperm production in two species of Australian arid zone rodents (Pseudomys australis, Notomys alexis) with marked differences in testis size, Reproduction, 121: 2001, 239-247.

[33]. M. Carretta Júnior, Avaliação morfofuncional do processo espermatogênico de pacas (Cuniculus paca, Linnaeus, 1766) adultas, master diss., Universidade Federal de Viçosa, Viçosa, MG, Brasil, 2008.

[34]. L. Johnson, D.D. Varner, M.E. Roberts, T.L. Smith, G.E. Keillor and W.L. Scrutchfield, Efficiency of spermatogenesis: a comparative approach, Animal of Reproduction Science, 60-61: 2000, 471-480.

[35]. L.R. França, G.F. Avelar and F.F.L. Almeida, Spermatogenesis and sperm transit through the epididymis in mammals with emphasis on pigs, Theriogenology, 63: 2005, 300-318.

[36]. A.C.S. Castro, W.E. Berndtson and F.M. Cardoso, Cinética e quantificação da espermatogênese: bases morfológicas e suas aplicações em estudos da reprodução de mamíferos, Revista Brasileira de Reprodução Animal, 21: 1997, $25-34$.

[37]. J.A. Collins, C.A. Schandi, K.K. Young, J. Vesely and M.C. Willingham, Major DNA fragmentation is a late event in apoptosis, Journal of Histochemistry and Cytochemistry, 45: 1997, 923-934.

[38]. S. Eaker, A. Pyle, J. Cobb and M.A. Handel, Evidence for meiotic spindle checkpoint from analysis of spermatocytes from Robertsonian-chromosome heterozygous mice, Journal of Cell Science, 114: 2001, 2953-2965.

[39]. P.K. Chaturvedi and L. Johnson, Architectural arrangement of stages of the spermatogenic cycle within human seminiferous tubules is related to efficiency of spermatogenesis, Cell \& Tissue Research, 273: 1993, 65-70.

[40]. D.S. Costa, C.M.C. Menezes and T.A.R. Paula, Spermatogenesis in white-lipped peccaries (Tayassu peccary), Animal Reproduction Science, 98: 2007, 322-334.

[41]. R.P. Amann, L. Johnson, D.L.J.R. Thompson and B. W. Pickett, Daily spermatozoal production, epididymal spermatozoal reserves and transit time of spermatozoa through the epididymis of the Rhesus monkey, Biology of Reproduction, 15: 1976, 586-592.

[42]. L. Johnson, Spermatogenesis and aging in the human, Journal of Andrology, 7: 1986, 331-354. 
[43]. L.D. Russell and M.D. Griswold, The Sertoli cell. (Cache River Press, Florida: Clearwater 1993).

[44]. T.A.R. Paula, L.R. França and H.C. Garcia, Seminiferous epithelium cycle and its duration in capybaras (Hydrochoerus hydrochaeris), Tissue \& Cell, 31: 1999, 327-334.

[45]. K.L.C. Costa, S.L.P. Matta, M.L.M.Gomes, T.A.R. Paula, K.M. Freitas, F.A.R. Carvalho, J.A. Silveira, H. Dolder, S.M.L.C. Mendis-Handagama, Histomorphometric evaluation of the neotropical brown brocket deer Mazama gouazoubira testis, with an emphasis on cell population indexes of spermatogenic yield, Animal Reproduction Science 127: 2011, 202-212.

[46]. A.L. Kierszenbaum and L.L. Tres, The acrosome-acroplaxome-manchette complex and the shaping of the spermatid head, Archives of Histology and Cytology, 67: 2004, 271-284.

[47]. A.L. Kierszenbaum and L. L. Tres, Spermatogenesis. in A.L. Kierszenbaum, L.L. Tres (Eds.), Histology and Cell Biology: An introduction to pathology (Rio de Janeiro: Elsevier, 2012) 587-615. 